\title{
Effect of Nitrogen and Phosphorous Fertilizer Application on Growth and Yield of Black Cumin Cultivation in Malda District (WB)
}

\author{
Samima Sultana ${ }^{*}$, Adwaita Mondal ${ }^{1}$, Srabani Das ${ }^{2}$, B.C. Rudra ${ }^{1}$, \\ Banaz Alam ${ }^{3}$ and Saurav Roy \\ ${ }^{1}$ Malda KVK, UBKV, India \\ ${ }^{2}$ Seva Bharati KVK, Kapgari, Jhargram, India \\ ${ }^{3}$ Jalpaiguri Krishi Vigyan Kendra, WBUFAS, India \\ ${ }^{4}$ Department of PSMA, BCKV, India \\ *Corresponding author
}

\section{Keywords}

Nigella, Black cumin, Inorganic fertilizer

\section{Article Info}

Accepted:

20 March 2019

Available Online:

10 April 2019
A B S T R A C T

Nigella (Nigella sativa L.) is a spice crop that belongs to Ranunculaceae family. The seeds or grains resembling onion seed, are used both as spice and medicine. In Malda district of WB, this crop do not cultivated earlier time but recent 2 to 3 Years it is introduced as a new seed spices which opens new avenues for the farmers by not only the choice of crops but also improve their revenue from the land. The present investigation was carried out during rabi 2017 and 2018 in the Malda district on, optimum N and P application levels to get high yield and quality in nigella four levels of nitrogen $(0,20,40$ and $60 \mathrm{~kg}$ nitrogen $\left.(\mathrm{N}) \mathrm{ha}^{-1}\right)$ and phosphorus $(0,15,30$ and $45 \mathrm{~kg}$ phosphorus $(\mathrm{P}) / \mathrm{ha}$. The study on application of different levels of nitrogen and phosphorus revealed that all the traits were influenced by $\mathrm{N}$ and $\mathrm{P}$ application. There was interaction effect in the traits like plant height $(60,90$ DAS and at harvest), capsule yield, husk yield. $\mathrm{N}$ and $\mathrm{P}$ application levels improved the plant height, number of leaves per plant and number of branches per plant at different stages of growth. Similar response was observed in fresh and dry matter accumulation. Minimum total chlorophyll content, The yield contributing characters like capsule weight at harvest, capsule length and diameter, number of capsules, number of seeds per capsule, test weight, capsule yield per plant and grain yield per plant increased with level of application of $\mathrm{N}$ and generally maximum values were observed in highest $\mathrm{N}$ application. Similar response was observed with $\mathrm{P}$ application. Seed yield and stalk yield were maximum at highest $\mathrm{N}$ application. Seed yield was maximum with the application of phosphorus 45 and $30 \mathrm{~kg} / \mathrm{ha}$. The uptake of $\mathrm{N}, \mathrm{P}$ and $\mathrm{K}$ increased with the increase of $\mathrm{N}$ and $\mathrm{P}$ applications. Lower available nitrogen and potassium, and higher available phosphorus status was observed after harvest than initial soil status. The highest Benefit Cost Ratio (BCR) was recorded with the crop sown during the October. The application of $60 / \mathrm{kg} \mathrm{N}$ ha in two splits as basal and at 35 DAS with 30. 


\section{Introduction}

Nigella (Nigella sativa L.) is a spice crop that belongs to Ranunculaceae, the butter cup family. The seeds or grains resembling onion seed, are used both as spice and medicine. It is believed to have originated in the Mediterranean region and subsequently spread to Europe, Asia and Africa. Seeds of this plant were used both as spice and medicine since a very long time. The seeds are bitter in taste and consumption of whole seed even in small quantity gives a feeling of constriction of throat. It is appropriately known as seed of blessing (habbatul barakah) (Srivastava, 2014). The spice was attributed with numerous medicinal properties and is widely used in unani, ayurveda, siddha and other ethnomedicine systems across the world (Padmaa, 2010). The medicinal value of the spice is immense and numerous workers appreciated its unique, varied and powerful pharmacological traits. The popularity of the plant was highly enhanced by the ideological belief in the herb as a cure for multiple diseases. likes anti-tumour anti-diabetic, cardioprotective, gastroprotective), antiasthmatic, nephroprotective, hepatoprotective, antiinflmmatory, immunomodulatory, neuroprotective, anticonvulsant, anxiolytic, antioxidant, antinociceptive, antioxytocic, contraceptive, antibacterial antifungal, and anthelmintic activities were immensely appreciated. The major medicinal components are thymoquinone and nigellone (a dimer of thymoquinone). These were attributed to impart anti-tumour, anti-inflammatory and anti-diabetic properties (Woo et al., 2012).

The crop is presently cultivated in parts of Asia, Africa, Europe and Americas of the globe. The major producing countries are India, Sri Lanka, Bangladesh, Afghanistan, Pakistan, Egypt, Iran, Iraq, Syria, Turkey and Ethiopia. In India, it is grown in many parts, particularly in Madhya Pradesh, Bihar, Punjab, Assam, Jammu and Kashmir, Himachal Pradesh, Uttar Pradesh, Rajasthan, West Bengal and Tamil Nadu. Among the countries that export black cumin, the major ones are India, Syria, Ethiopia and Turkey. The major seed spices grown in West Bengal are coriander, fenugreek, cumin, black cumin and Fennel. Nigella though found suitable as rabi crop for West Bengal. In Malda district of WB, this crop do not cultivated earlier time but recent 2 to 3 Years it is introduced as a new seed spices which opens new avenues for the farmers by not only the choice of crops but also improve their revenue from the land. The present investigation was carried out during rabi 2017 and 2018 in the Malda district on, optimum $\mathrm{N}$ and $\mathrm{P}$ application levels to get high yield and quality in nigella four levels of nitrogen $(0,20,40$ and $60 \mathrm{~kg}$ nitrogen $(\mathrm{N})$ ha-1) and phosphorus $(0,15,30$ and $45 \mathrm{~kg}$ phosphorus $(\mathrm{P}) / \mathrm{h}$. The study on application of different levels of nitrogen and phosphorus revealed that all the traits were influenced by $\mathrm{N}$ and $\mathrm{P}$ application.

\section{Materials and Methods}

The experiment was conducted in farmer's field of Malda district, West Bengal, India, during the year 2017-18 with high yielding black cumin variety. Geographically, experimental site situated at $23.5^{\circ}$ North latitude, $89^{\circ}$ East longitude having an average altitude of $9.75 \mathrm{~m}$ above mean sea level. The experimental site was located in sub-tropical humid climate with gangetic old alluvial soil, sandy clay loam texture, good water holding capacity, well drained, and with acidic to neutral reaction and moderate fertility status. The experiment Design was randomized block design (RBD) with four (8) treatments. The treatments are four levels of nitrogen $(0$, 20,40 and $60 \mathrm{~kg}$ nitrogen $\left.(\mathrm{N}) \mathrm{ha}^{-1}\right)$ and phosphorus $(0,15,30$ and $45 \mathrm{~kg}$ phosphorus (P)/ ha. The experiment land was plowed, 
cultivated and then prepared for seed sowing through broadcasting method. For the experiment on different dates of sowing well rotten farm yard manure was applied as a basal dose at the rate of 20 quintal per hectare. The crop was fertilized with nitrogen, phosphorus form of urea, single super phosphate respectively. The application of 60 $/ \mathrm{kg} \mathrm{N}$ ha in two splits as basal and at 35 DAS with 30 and full dose of ssp was applied as basal. Seeds were sown by hand in mid week of October in the ratio of $15 \mathrm{~kg} / \mathrm{ha}$. The distance between rows was $20 \mathrm{~cm}$ and within the rows were $5 \mathrm{~cm}$. Seeds were sowed at 1-2 cm depths soil.

The crop was irrigated immediately after sowing for obtaining better and uniform germination. Subsequent irrigation were given as when require to maintain uniform soil moisture throughout the crop growth period. Immediately after the germination of the seeds, gap filling was taken up to maintain uniform plant population. First thinning was taken up to maintain optimum plant population at 15 DAS and second thinning was taken up 10 days after the first thinning. The experimental plot was kept weed free throughout the crop growth period with supplementary hand weeding and plant protection was taken time to time. The crop was harvested at maturity when the capsules turned to brown colour and dried. Harvesting was done by pulling the plants. The border rows from each plot were harvested first leaving the net plot area. Later, net plot area was harvested after separating the plants designated for recording biometrical observations. The harvested plants were sundried for three days and threshing was done by beating with sticks. The seed was winnowed and cleaned subsequently for recording yield data

\section{Observations on the crop}

Plant height, no of branches per plant, yield/ha was recorded.

\section{Results and Discussion}

The interaction of $\mathrm{N}$ and $\mathrm{P}$ on plant height was found significantly higher. The maximum plant height was recorded with application of $60 \mathrm{~kg}$ ha-1 $\mathrm{N}$ and $45 \mathrm{~kg}$ ha-1 $\mathrm{P}$. The increase in plant height with increased application of $\mathrm{P}$ may be due to its influence on cell division, development of new tissue, and growth as reported by M'onas (2013) and Dutta et al., (2008).

The increase in number of branches with increase in nitrogen application can be attributed to the regular supply of $\mathrm{N}$ which might have enhanced the branching ability and production of vegetative buds (Table 1$3)$.

Table.1

\begin{tabular}{|c|c|c|c|c|c|c|c|}
\hline \multirow{2}{*}{$\begin{array}{l}\text { Nitrogen } \\
\text { ( kg/ha ) }\end{array}$} & \multicolumn{7}{|c|}{ Phosphorus ( kg/ha) - Seed Yield (Q/Ha) } \\
\hline & 0 & 15 & 30 & 45 & Mean & SEm \pm & $\mathrm{CD}(0.05)$ \\
\hline 0 & 2.6 & 3.2 & 3.9 & 4.04 & 3.44 & \multirow[t]{4}{*}{0.19} & \multirow[t]{4}{*}{0.38} \\
\hline 20 & 3.6 & 4.05 & 4.6 & 4.76 & 4.25 & & \\
\hline 40 & 3.8 & 4.04 & 4.68 & 4.97 & 4.37 & & \\
\hline 60 & 3.9 & 4.70 & 4.98 & 5.25 & 4.71 & & \\
\hline Mean & 3.48 & 4.00 & 4.54 & 4.76 & & & \\
\hline \multicolumn{6}{|l|}{ SEm \pm} & \multicolumn{2}{|l|}{0.14} \\
\hline \multicolumn{6}{|l|}{$\mathrm{CD}(0.05)$} & \multicolumn{2}{|l|}{0.37} \\
\hline
\end{tabular}


Table.2

\begin{tabular}{|c|c|c|c|c|c|c|c|}
\hline \multirow{2}{*}{$\begin{array}{l}\text { Nitrogen } \\
\text { ( kg/ha ) }\end{array}$} & \multicolumn{7}{|c|}{ Phosphorus ( kg/ha) - Plant Height $(\mathrm{Cm})$} \\
\hline & 0 & 15 & 30 & 45 & Mean & SEm \pm & $\mathrm{CD}(0.05)$ \\
\hline 0 & 33 & 35.7 & 36.37 & 36.8 & 35.4675 & \multirow[t]{4}{*}{0.67} & \multirow[t]{4}{*}{2.11} \\
\hline 20 & 35.2 & 41.2 & 41.5 & 38.7 & 39.15 & & \\
\hline 40 & 37.2 & 41 & 43.4 & 46.2 & 41.95 & & \\
\hline 60 & 36.2 & 42.5 & 45.2 & 47.3 & 42.8 & & \\
\hline Mean & 35.4 & 40.1 & 41.61 & 42.25 & & & \\
\hline \multicolumn{6}{|l|}{ SEm \pm} & \multicolumn{2}{|l|}{0.64} \\
\hline \multicolumn{6}{|l|}{$\mathrm{CD}(0.05)$} & \multicolumn{2}{|l|}{1.97} \\
\hline
\end{tabular}

Table.3

\begin{tabular}{|c|c|c|c|c|c|c|c|}
\hline \multirow{2}{*}{$\begin{array}{l}\text { Nitrogen } \\
\text { ( kg/ha ) }\end{array}$} & \multicolumn{7}{|c|}{ Phosphorus ( kg/ha) - No of branches /plant } \\
\hline & 0 & 15 & 30 & 45 & Mean & SEm \pm & $\mathrm{CD}(0.05)$ \\
\hline 0 & 6 & 7 & 7 & 7 & 6.75 & \multirow[t]{4}{*}{0.13} & \multirow[t]{4}{*}{0.42} \\
\hline 20 & 7 & 8 & 8 & 8 & 7.75 & & \\
\hline 40 & 8 & 9 & 9 & 8 & 8.5 & & \\
\hline 60 & 8 & 9 & 9 & 10 & 9 & & \\
\hline mean & 7.25 & 8.25 & 8.25 & 8.25 & & & \\
\hline \multicolumn{6}{|l|}{ SEm \pm} & \multicolumn{2}{|l|}{0.13} \\
\hline \multicolumn{6}{|l|}{$\mathrm{CD}(0.05)$} & \multicolumn{2}{|l|}{0.47} \\
\hline
\end{tabular}

The positive influence of $\mathrm{P}$ application on number of branches may be due to the increased availability of nitrogen and potassium which resulted in better plant growth (Garg and Malhotra, 2008). The highest phosphorus application and nitrogen application gave highest seed yield (Kheradmand et al., 2014).

In conclusion, the uptake of all the three macronutrients $\mathrm{N}, \mathrm{P}$ and $\mathrm{K}$ studied increased with the increase of $\mathrm{N}$ and $\mathrm{P}$ applications. At all the stages of growth, $\mathrm{N}$ and $\mathrm{P}$ uptake increased up to $40 \mathrm{~kg} \mathrm{~N} \mathrm{ha}^{-1}$ and $30 \mathrm{~kg} \mathrm{ha}^{-1}$ phosphorus application. Hence, it can be recommended that the economic returns and profitability of the crop can be enhanced by the application of $60 \mathrm{~kg} \mathrm{~N} \mathrm{ha}^{-1}$ and $30 \mathrm{~kg} \mathrm{P}$ $\mathrm{ha}^{-1}$.

\section{References}

Dutta, D., Bandyopadhyay, P. and Maiti, D. 2008. Effect of $\mathrm{P}$ fertilization and growth regulators on yield, nutrient uptake and economics of fenugreek (Trigonella foenum graecum L.). Research on Crops. 9(3): 599-601.

M'onas, A.H.M. 2013. The Effect of Different Levels of Nitrogen and Phosphate Fertilization on Oil Rate in Nigella sativa Seeds. AL-Qadisiya Journal for Agriculture Sciences. 3 (2): 12-27.

Garg, V.K. and Malhotra, S. 2008. Response of Nigella sativa L. to fertilizers under sodic soil conditions. Journal of Medicinal and Aromatic Plant Sciences. 30: 122-125.

Kheradmand, S., Moteghi, H.S., Kord, H. and 
Vaezy, Z. 2014. Effect of nitrogen fertilizer application on yield and yield components herb Nigella sativa under different humidity conditions. International Journal of Research in Agriculture and Environment Science. 3
(1): 18-22, 2014

Srivastava, B. (2014). Medicinal and therapeutical potential of Nigella sativa. International journal of medical and applied sciences research. 1 (1): 32- 39.

\section{How to cite this article:}

Samima Sultana, Adwaita Mondal, Srabani Das, B.C. Rudra, Banaz Alam and Saurav Roy. 2019. Effect of Nitrogen and Phosphorous Fertilizer Application on Growth and Yield of Black Cumin Cultivation in Malda District (WB). Int.J.Curr.Microbiol.App.Sci. 8(04): 2813-2817. doi: https://doi.org/10.20546/ijcmas.2019.804.328 